\title{
A palynological study from Sweden reveals stable terrestrial environments during Late Silurian extreme marine conditions
}

\author{
Kristina Mehlqvist, Jane Wigforss-Lange and Vivi Vajda \\ Department of Geology, Lund University, Sölvegatan 12, SE-223 62 Lund, Sweden. \\ Email: Kristina.Mehlqvist@geol.lu.se
}

\begin{abstract}
A palynological study of the upper Silurian Öved-Ramsåsa Group in Skåne, Sweden yields a well preserved spore assemblage with low relative abundances of marine microfossils. In total, 26 spore taxa represented by 15 genera were identified. The spore assemblage is dominated by long-ranging cryptospore taxa, and the trilete spore Ambitisporites avitus-dilutus. However, key-species identified include Artemopyra radiata, Hispanaediscus lamontii, H. major, $H$. verrucatus, Scylaspora scripta and Synorisporites cf. libycus. Importantly, Scylaspora klintaensis was identified, allowing correlation with the Klinta 1 drillcore (Skåne). A Ludlow age is inferred for the exposed succession, which agrees well with previous conodont stratigraphy. The organic residue is dominated by phytodebris and spores, but with high relative abundances of acritarchs at two levels, possibly related to flooding surfaces.

Based on the palynofacies analysis, a near-shore marine environment is proposed. The close proximity to land is inferred by the high proportions of spores, and the dispersed assemblage most likely represents the local flora growing on delta plains. The palynological signal also infers a stable terrestrial environment and vegetation, in contrast to unstable conditions in the marine environment characterised by ooid formation in an evaporitic environment. Comparisons with coeval spore assemblages from Gotland, Avalonia and Laurentia show relatively close similarities in taxonomic composition at the generic level.
\end{abstract}

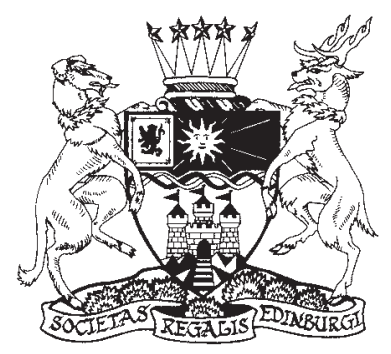

KEY WORDS: cryptospores, early land plants, Klinta, Ludfordian, sea level, stratigraphy

Records of early land plants from Baltica have previously been described from Röstånga, Skåne (Sweden). These Late Ordovician (Katian) spores represent the oldest record of land plants from Baltica (Badawy et al. 2014). Other records of cryptospores are from Ordovician (latest Katian-Hirnantian) deposits from the Valga-10 core in southern Estonia (Vecoli et al. 2011). Studies concerning terrestrial palynomorphs from the top Ordovician to the Wenlock successions of Baltica are scarce, but middle Llandovery to late Ludlow spore assemblages were described by Hagström (1997) from the Närborrningen 1 and Burgsvikborrningen 1 cores and from outcrops on Gotland. A rich and well-preserved palynoflora of cryptospores, vascular plant spores, fungal spores and hyphae was recovered especially from the Ludfordian Burgsvik Beds by Hagström (1997). Sherwood-Pike \& Gray (1985) also reported fungal spores and hyphae from these beds. Silurian spores have also been studied from Skåne and Gotland by Gray et al. (1974). Hagström \& Mehlqvist (2012) described further early (Ludlow) land plant remains from Gotland. Upper Silurian outcrop sections and bore cores from Skåne have also yielded spore assemblages (Mehlqvist et al. 2012, 2014).

The upper Silurian Öved-Ramsåsa Group in Skåne, Sweden has been subjected to numerous investigations over the two last centuries. The strata representing the youngest Palaeozoic are mainly exposed in limestone and sandstone quarries, and along the shore of Lake Ringsjön, the so-called Klinta exposure. The first publication, from 1725, is a documentation of the fossil content (Bromell 1725-1729). Succeeding comprehensive publications concerning the exposed successions at Klinta include, for example, Eichstädt (1888), Grönwall (1897), Hadding (1927, 1933), Regnéll (1960); and detailed studies comprise research on conodonts (Jeppsson 1975; Jeppsson \& Laufeld 1986), tentaculitids (Larsson 1979), chitinozoans (Grahn 1996) and $\delta{ }^{13} \mathrm{C}$ composition (Wigforss-Lange 1999; Jeppsson et al. 2012). However, all these studies focus on the marine microfossils or sedimentological/geochemical aspects and no contributions concern terrestrial microfossils. Our study focuses on upper Silurian successions from southern Sweden, with the aim of describing the dispersed spore assemblages and other organic debris recovered from exposures at Klinta, providing the first record of terrestrial palynology in these strata. We correlate our results with zonation schemes based on marine microfossils and compare our terrestrial palynological signal to the environmental changes within the marine realm.

\section{Geological setting}

By the time of the Silurian, Baltica was located south of the Equator in the tropical climate zone (Fig. 1a; Moore et al. 1994). The platform was partly covered by an epicontinental sea and remnants of Silurian deposits are found in Norway, mid and south Sweden, the Baltic Sea, the East Baltic States, Denmark and Poland. The Baltoscandian Platform was, during the Palaeozoic, strongly affected by the Caledonian orogenic cycle that resulted in the collision of the continents Laurentia, Baltica and Avalonia (Fig 1a). The Iapetus and Rheic Oceans were closing up and the active fold belts on the western and southeastern margins of the Baltic platform formed the ArcticNorth Atlantic Caledonides and the North German-Polish Caledonides (Frost et al. 1981; Ziegler 1984; Zeh \& Gerdes 2010). The former, wide shelf areas transformed to marginal basins where clastics, derived from the mountain ranges, were 

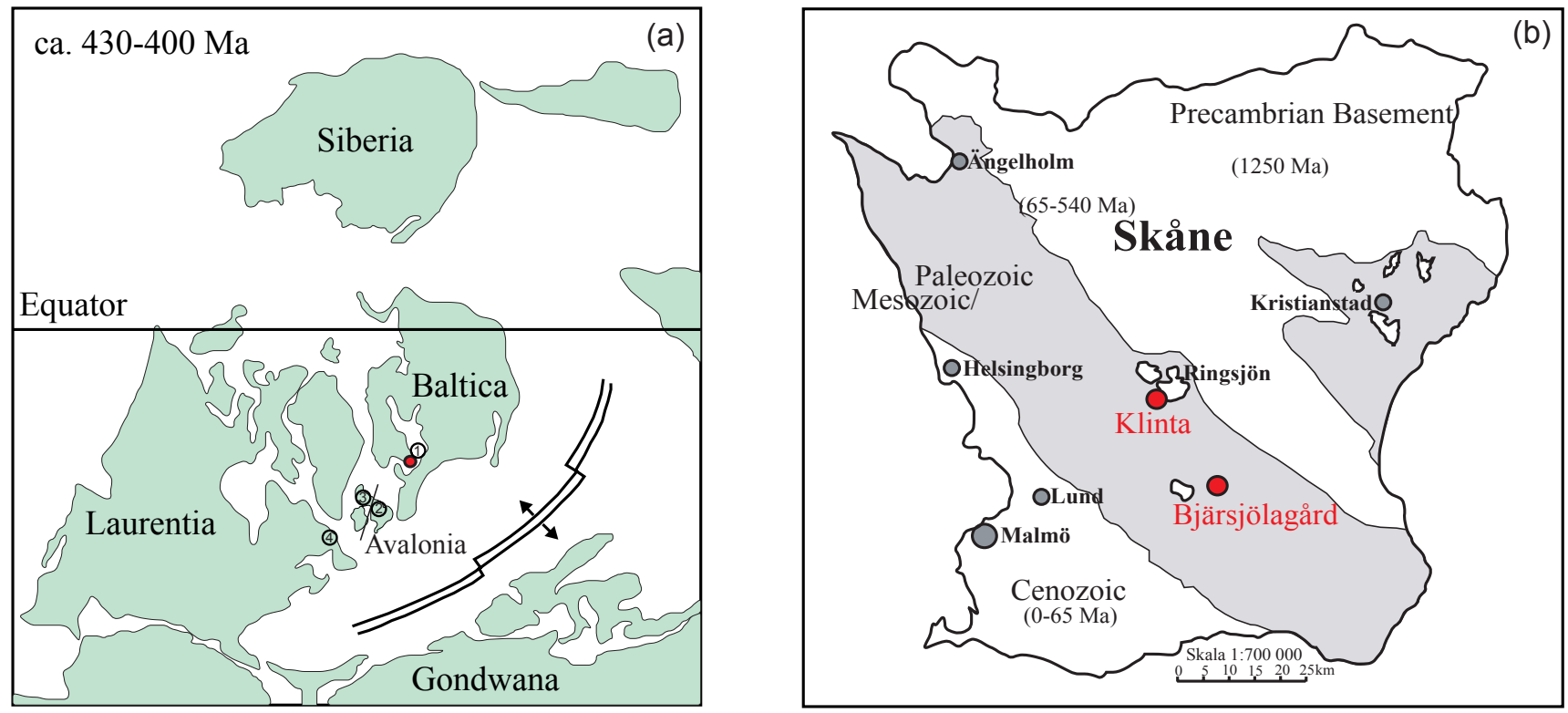

Figure 1 (a) Palaeogeographic map showing the position of Baltica, during the late Silurian to Early Devonian. Red circle marks the study site in Skåne, Sweden. Numbers show the location of other study sites, compared with Klinta: 1 = Gotland; 2 = Wales; 3 = Scotland; 4 = Nova Scotia. (Map modified after Scotese et al. 1985). (b) The principal exposures of the Öved Ramsåsa Group are found in Klinta and Bjärsjölagård, Sweden (Locality map modified after Wikman \& Bergström 1987).

deposited (Zeh \& Gerdes 2010). The sedimentary strata reflect a gradual shallowing-up from deep-water graptolitic shales to shallow marine limestones and sandstones. Following the prograding, shoreline marine deposition ceased, as indicated by the onset of early Devonian "Old Red Sandstone" deposition (Bassett 1985).

The youngest Palaeozoic stratum in southern Sweden is the Öved-Ramsåsa Group, which is sub-divided into the Klinta Formation (Jeppsson \& Laufeld 1986) and the overlying Öveds Sandstone Formation (Hadding 1927). These sediments are dominated by mudstones, inter-layered with shallow marine carbonates, grading into sandstones in the younger part of the succession. The majority of the outcrops representing the Öved-Ramsåsa Group are found in central Skåne at Klinta and Bjärsjölagård (Fig. 1b). The Klinta exposures are located along the shoreline of the eastern lake Ringsjön (Figs 1b, 2).
In sedimentological and petrographic studies, these deposits have been shown to contain cerebroid ooids and evaporite tracers, which are linked to changes in faunas (Wigforss-Lange 2007; Jeppsson et al. 2012). The depositional setting has been interpreted as a near-shore tidally-influenced environment grading from open marine shallow subtidal to lagoonal intertidal conditions (Wigforss-Lange 2007).

The present stratigraphical scheme and nomenclature for the Öved-Ramsåsa Group is primarily based on conodont stratigraphy established by Jeppsson (1975) and Jeppsson \& Laufeld (1986), and on spores from land plants studied from the drillcores Klinta 1 and Bjärsjölagård 2 (Mehlqvist et al. 2012).

The section at Klinta investigated herein comprises the Bjär and Bjärsjö members containing the conodont faunas Ozarkodina excavata (former Hindeodella excavata), older

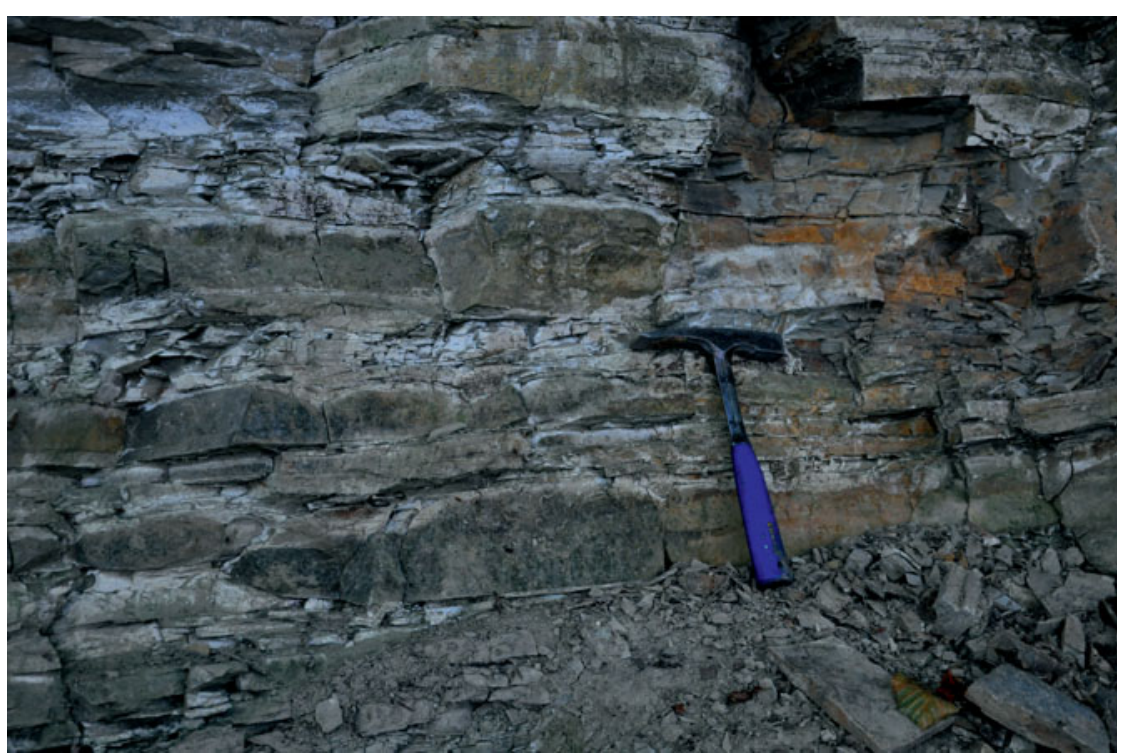

Figure 2 One of the studied exposures at Klinta, located by the shore of the eastern Lake Ringsjön, Sweden. 
Table I

Raw data, \% of spore taxa identified in each sample. Taxa highlighted in yellow are trilete spore species; the rest are cryptospores.

\begin{tabular}{|c|c|c|c|c|c|c|c|c|c|c|c|c|c|c|c|c|c|c|c|c|c|c|c|c|c|c|c|}
\hline 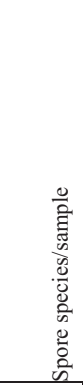 & 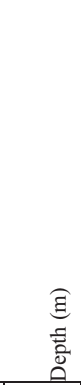 & 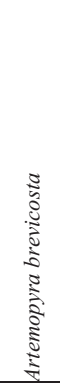 & 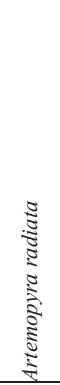 & 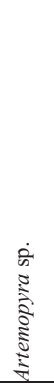 & 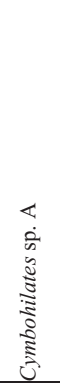 & 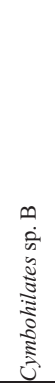 & 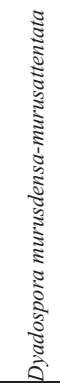 & 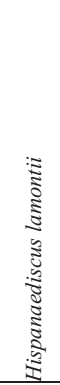 & 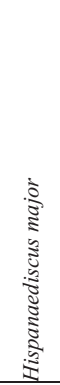 & 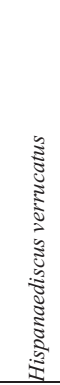 & 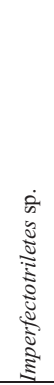 & 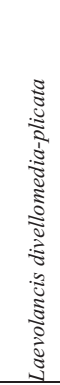 & 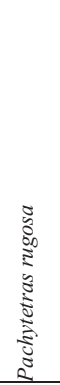 & 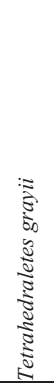 & 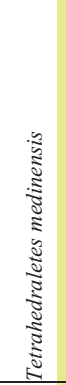 & 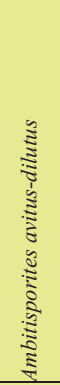 & 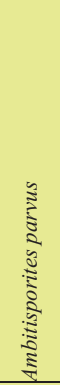 & 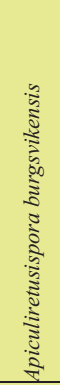 & 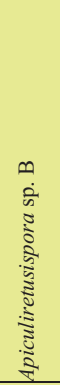 & 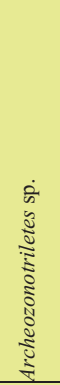 & 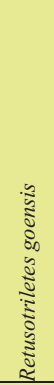 & 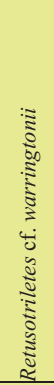 & 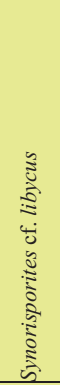 & 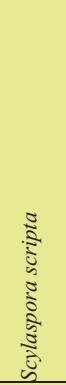 & 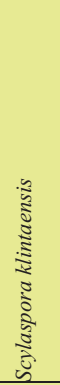 & 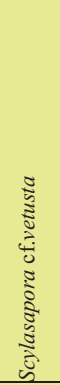 & 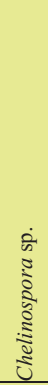 \\
\hline 93-3 & 14.08 & 0 & 0 & 0 & 0.7 & 0 & 5.3 & 0 & 0 & 0 & 4.6 & 81.6 & 0 & 0 & 0 & 2.0 & 1.3 & 0 & 0 & 0 & 0 & 2.6 & 0 & 0 & 2.0 & 0 & 0 \\
\hline $93-16$ & $\mid 13.83$ & 0 & 0 & 0 & 0 & 0 & 6.3 & 0 & 0 & 0 & 0 & 89.9 & 0 & 0 & 0 & 3.8 & 0 & 0 & 0 & 0 & 0 & 0 & 0 & 0 & 0 & 0 & 0 \\
\hline 93-2 & 13.36 & 0 & 0 & 0 & 0.7 & 0,7 & 2.6 & 0 & 0 & 0 & 4.6 & 82.2 & 0 & 0 & 0,7 & 7.2 & 0.7 & 0 & 0 & 0 & 0 & 0 & 0 & 0 & 0 & 0 & 0.7 \\
\hline 93-96 & 12.56 & 0 & 0 & 0 & 0 & 1,3 & 8.6 & 0.7 & 0 & 0 & 0 & 76.3 & 0 & 0.7 & 0 & 9.9 & 0 & 0 & 0.7 & 0 & 0 & 0.7 & 0 & 1.3 & 0 & 0 & 0 \\
\hline 93-8 & 11.18 & 0 & 0 & 0 & 1.3 & 0 & 9.3 & 0 & 0.7 & 2.0 & 0 & 62.3 & 8.6 & 0.7 & 3.3 & 9.3 & 0 & 0 & 0.7 & 0 & 0 & 2.0 & 0 & 0 & 0 & 0 & 0 \\
\hline 93-91 & 11.06 & 0 & 0,7 & 0 & 0 & 0 & 11.2 & 0 & 0 & 0.7 & 1.3 & 75.7 & 0.7 & 0.7 & 0 & 9.2 & 0 & 0 & 0 & 0 & 0 & 0 & 0 & 0 & 0 & 0 & 0 \\
\hline $93-80$ & 9.73 & 0 & 0 & 0 & 4.0 & 0 & 3.2 & 0 & 2.4 & 30.6 & 4.0 & 28.2 & 3.2 & 7.3 & 0.8 & 8.9 & 0.8 & 0 & 0 & 0.8 & 0.8 & 4.8 & 0 & 0 & 0 & 0 & 0 \\
\hline $93-76$ & 9.07 & 0 & 0 & 0 & 0 & 0 & 1.3 & 0 & 0 & 0 & 0 & 58.9 & 0 & 1.3 & 19.9 & 8.6 & 0 & 4.6 & 0 & 0 & 0 & 5.3 & 0 & 0 & 0 & 0 & 0 \\
\hline 93-23 & 8.87 & 0 & 0 & 0 & 0 & 0 & 9.2 & 0.7 & 0 & 0 & 1.3 & 82.4 & 0 & 2.6 & 0 & 2.0 & 0 & 0 & 0 & 0 & 0 & 2.0 & 0 & 0 & 0 & 0 & 0 \\
\hline 93-22 & 8.30 & 0 & 0 & 0 & 0 & 0 & 5.2 & 0 & 0 & 3.9 & 0 & 87.6 & 0 & 0.7 & 0 & 2.6 & 0 & 0 & 0 & 0 & 0 & 0 & 0 & 0 & 0 & 0 & 0 \\
\hline $93-35$ & 6.54 & 0 & 0 & 0 & 0.7 & 0 & 14.5 & 1.3 & 0 & 0 & 0 & 76.3 & 0 & 0 & 0.7 & 5.3 & 0.7 & 0.7 & 0 & 0 & 0 & 0 & 0 & 0 & 0 & 0 & 0 \\
\hline 93-33 & 6.25 & 0 & 0,7 & 0 & 0 & 0,7 & 11.9 & 7.9 & 0 & 0 & 0 & 64.2 & 0 & 2.6 & 0 & 7.9 & 0.7 & 0 & 0 & 0 & 0 & 2.6 & 0 & 0.7 & 0 & 0 & 0 \\
\hline 93-49 & 4.75 & 1.3 & 0 & 1.9 & 0 & 0 & 7.0 & 0 & 0 & 1.3 & 0 & 85.4 & 0 & 0 & 0.6 & 1.3 & 0.6 & 0 & 0 & 0 & 0 & 0 & 0 & 0 & 0 & 0,6 & 0 \\
\hline 93-48 & 4.26 & 0 & 0 & 0 & 0 & 0 & 15.5 & 0 & 0 & 0 & 0 & 78.0 & 0 & 0 & 2.4 & 2.4 & 1.8 & 0 & 0 & 0 & 0 & 0 & 0 & 0 & 0 & 0 & 0 \\
\hline $93-71$ & 3.95 & 0 & 0 & 0 & 0.6 & 0 & 14.8 & 1.3 & 0.6 & 0 & 3.2 & 64.5 & 0 & 4.5 & 0 & 2.6 & 0 & 0 & 4.5 & 0 & 0 & 0 & 3.2 & 0 & 0 & 0 & 0 \\
\hline 93-47 & 3.85 & 0 & 0 & 1 & 0.6 & 0 & 10.3 & 0 & 0 & 0 & 0 & 79.5 & 0 & 0 & 1.9 & 6.4 & 0 & 0 & 0 & 0 & 0 & 0 & 0.6 & 0 & 0 & 0 & 0 \\
\hline 93-46 & 2.58 & 0 & 0 & 0 & 0 & 0 & 2.0 & 0 & 0 & 1.3 & 0 & 89.9 & 0 & 0 & 0 & 4.7 & 0 & 0 & 0 & 0 & 0 & 1.3 & 0.7 & 0 & 0 & 0 & 0 \\
\hline $93-45$ & 1.75 & 0 & 0 & 0 & 1.2 & 0 & 1.2 & 0 & 0 & 0 & 0 & 87.7 & 0 & 3.7 & 1.2 & 2.5 & 0.6 & 0 & 0 & 0 & 0 & 1.2 & 0 & 0 & 0 & 0 & 0.6 \\
\hline 93-42 & 1.08 & 0 & 0 & 0 & 1.3 & 0 & 1.3 & 0 & 0 & 0 & 0 & 87.3 & 0 & 0 & 4.4 & 5.1 & 0 & 0 & 0 & 0 & 0 & 0.6 & 0 & 0 & 0 & 0 & 0 \\
\hline 93-37 & 0.00 & 0 & 0 & 0 & 0.7 & 0 & 0.7 & 0 & 0 & 0 & 0 & 69.1 & 0 & 2.7 & 4.7 & 8.7 & 0 & 12.1 & 0 & 0 & 0 & 1.3 & 0 & 0 & 0 & 0 & 0 \\
\hline
\end{tabular}

and younger Ozarkodina scanica (former Hindeodella steinhornensis scanica) of the Polygnathoides siluricus Zone and the Icriodontid Zone (Jeppsson 1975, table 1; Jeppsson et al. 2012, fig. 2). These faunas indicate a Ludlow (Ludfordian) age.

\section{Material and methods}

\subsection{Sampling}

The Klinta outcrop $\left(55.8640^{\circ} \mathrm{N}, 13.5110^{\circ} \mathrm{E}\right)$ is a $600 \mathrm{~m}$-long exposure along the shoreline of eastern Lake Ringsjön (Figs $1 \mathrm{~b} ; 2)$. The cliff face is $6 \mathrm{~m}$ high, but since the strata dip $18^{\circ}$ to the south, the succession becomes progressively younger in that direction. In 1996, one of the authors (W-L) excavated the cliff face and sampled five stratigraphic sections each separated by $30 \mathrm{~m}$. The resulting composite log, based on correlations outlined by Wigforss-Lange $(1999,2007)$, represents a continuous section with a thickness of $14 \mathrm{~m}$.

\subsection{Palynology}

Twenty samples were selected for palynological analysis and the samples were processed according to standard palynological procedures at Global GeoLab Ltd., Canada. About $20 \mathrm{~g}$ of sediment were first treated with dilute hydrochloric acid $(\mathrm{HCl})$ to remove calcium carbonate, and further macerated in $45 \%$ hydrofluoric acid (HF). No oxidation of the residues was performed, since the palynomorphs are of low thermal maturity. The organic residue was sieved using a $10-\mu \mathrm{m}$ mesh and mounted in epoxy resin on two microscopic slides. 150 spores were identified per slide and the percentage of each spore taxa was calculated (Fig. 3; Table I). Some morphotaxa and similar taxa have been combined in the diagrams (Figs 3, 4).

\subsection{Palynofacies}

Palynofacies analysis involved counting the relative abundance of organic particles based on 1,000 counts per slide. Classification of palynological matter was based on Batten's (1996) scheme adjusted to the local palynofacies, therefore not all sub-groups from Batten's classification system are represented within this study: I. Spores (from early land plants); II. Black phytodebris; III. Brown phytodebris; IV. Cuticle-like sheets; V. Tubular structures; VI. Acritarchs; VII. Scolecodonts; and VIII. Chitinozoans (Fig. 5). The slides and residues are deposited at the Department of Geology at Lund University and illustrated specimens are identified by LO numbers.

\section{Results}

\subsection{Palynology and age determination}

A well preserved spore assemblage represented by 26 spore taxa in 15 genera was identified. Marine microfossils are represented by acritarchs (Fig. 6) that occur in all samples, together with low relative abundances of chitinozoans and scolecodonts occurring in a few samples (Fig. 5).

The spore assemblages are dominated by cryptospores, which are represented by 14 species in eight genera, and by trilete spores, represented by 12 species in seven genera. The morphotaxa Laevolancis divellomedia and L. plicata are the overall dominant taxa and together make up c.28-90\%. Dyadospora murusdensa-murusattenuata makes up 0.7-15.5\% (average $5 \%$ ); and Ambitisporites avitus reaches a maximum relative abundance of $10 \%$ of the total spore count. Biostratigraphically important species include Artemopyra brevicosta, 


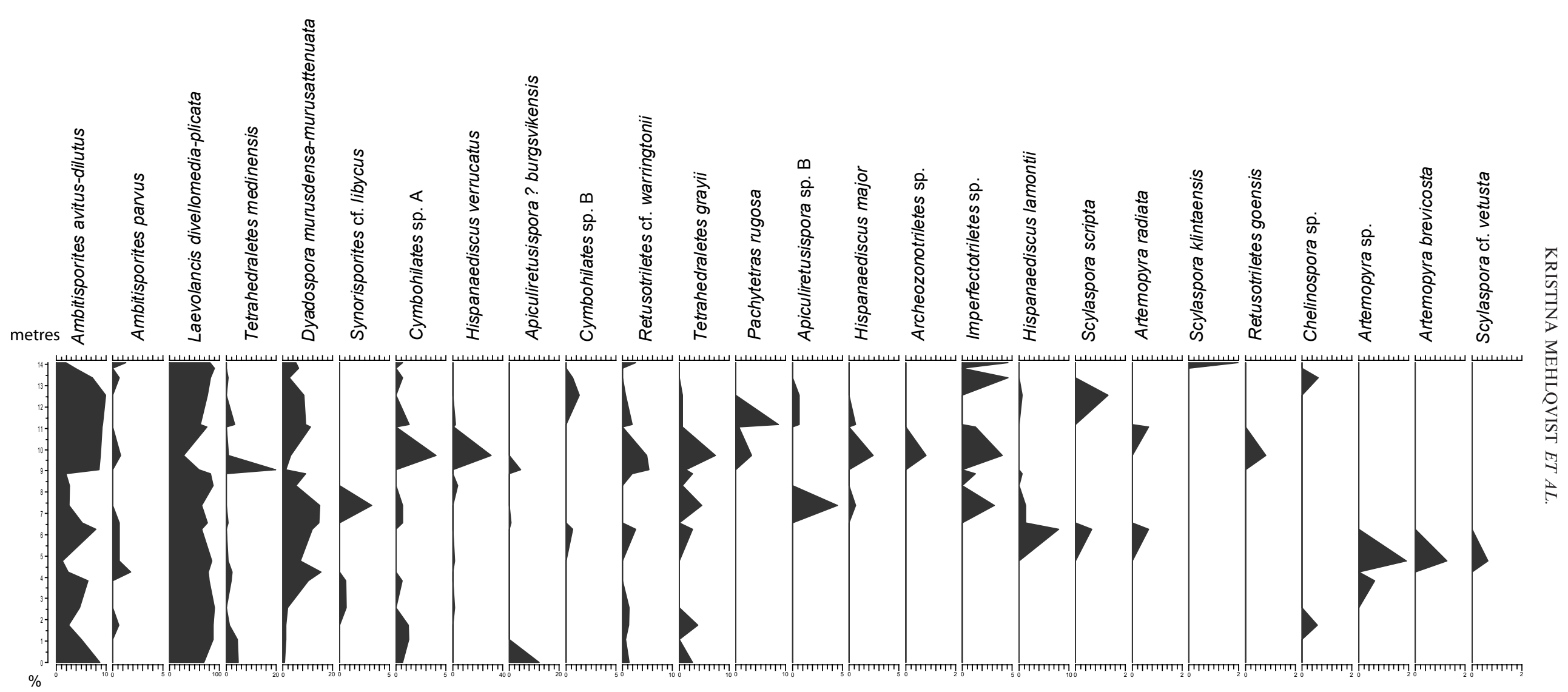

Figure 3 Spore diagram illustrating the relative abundance of selected spore taxa identified in the studied samples from the Klinta exposure. Note the different $\%$ scales on $\mathrm{x}$-axes. 


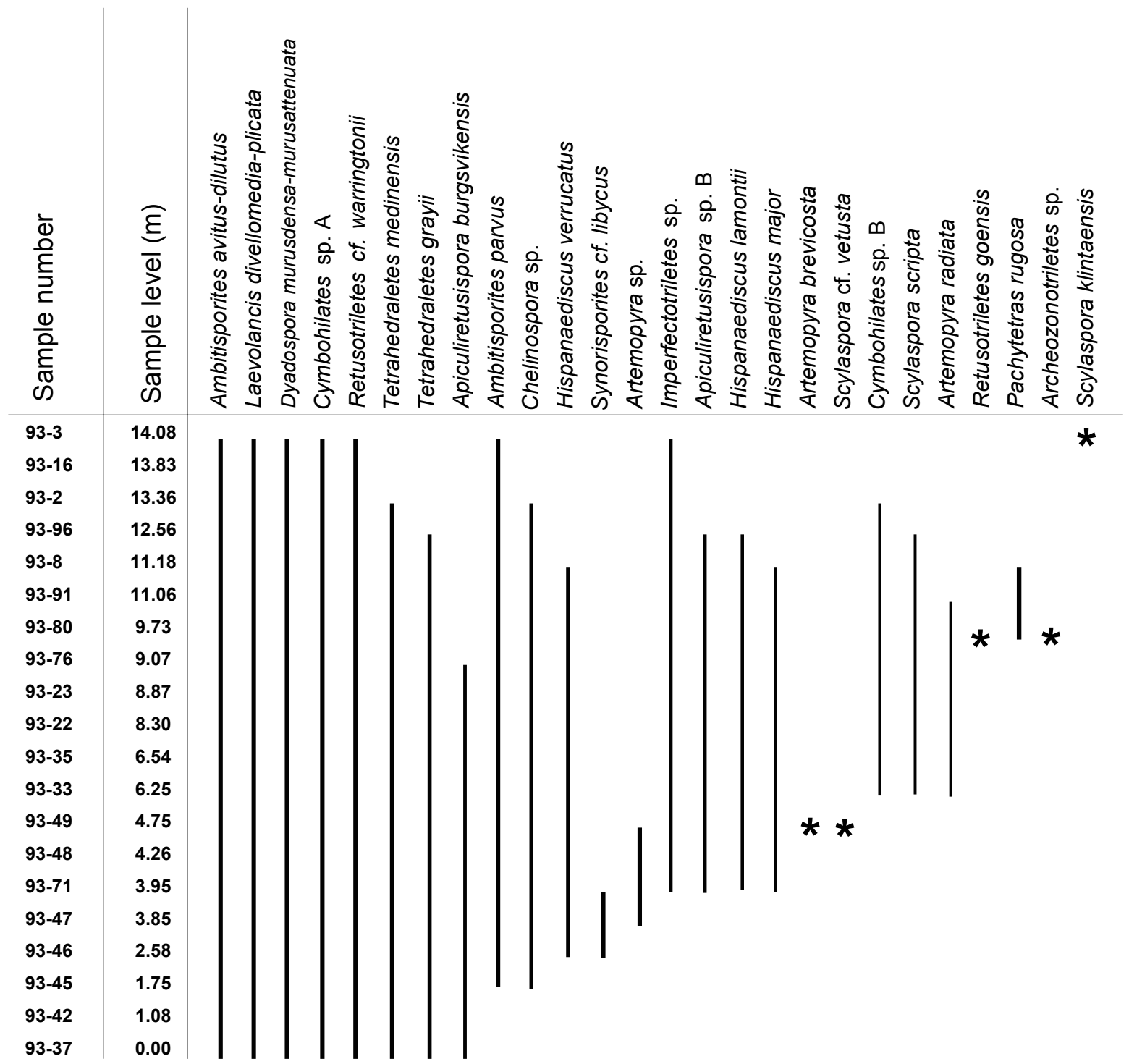

Figure 4 Range-chart for selected spore taxa through the Klinta outcrop succession. Stars represent occurrence in only one sample.

Artemopyra radiata, Hispanaediscus lamontii, $H$. major, $H$. verrucatus, Scylaspora scripta and Synorisporites cf. libycus (Fig. 7). Further, Scylaspora klintaensis occurs in the uppermost sample 93-3 at $14.08 \mathrm{~m}$ (Figs 3, 4; Table 1). This species was previously described from the Klinta 1 drillcore with a first appearance datum (FAD) at $112 \mathrm{~m}$ (Mehlqvist et al. 2012). This provides a tentative correlation between the outcrop section and the drillcore Klinta 1.

\subsection{Palynofacies analysis}

The organic matter is, in most samples, dominated by either black and brown phytoclasts or spores (Fig. 5). However, acritarchs reach high relative abundances at two levels through the sampled succession, reaching $64 \%$ at $11 \mathrm{~m}$. Chitinozoans and scolecodonts only occur in low numbers and do not exceed $2 \%$ in any sample. Cuticle-like sheets and tubular structures are present with a few specimens in the basal part of the succession, not exceeding $1 \%$.

\section{Geological and palaeoenvironmental implications}

The succession has previously been dated to Ludfordian, based on the presence of the mid-Ludfordian conodont zones Polygnathoides siluricus and Icriodontid (Jeppsson et al. 2012) and by the presence of chitinozoans representing the Angochitina echinata chitinozoan zone (Grahn 1996). For a detailed biostratigraphic zonation scheme, see Mehlqvist et al. (2014).

The age assessments previously performed on marine microfossils are supported by our palynological study revealing a Ludlow age, as the spore assemblage can be equated with the Synorisporites libycus-Lophozonotriletes poecilomorphus Assemblage Zone of Richardson \& McGregor (1986). It should, however, be noted that the Assemblage Zone of Richardson \& McGregor (1986) was established in Avalonia and, whilst the zone can be broadly correlated between Avalonia and Baltica, a more precise correlation is perhaps not possible. Importantly, our results can now be used for a spore zonation scheme for Baltica, representing a typical Ludfordian spore assemblage.

We have compared our results with a coeval spore assemblage from nearby drillcore successions (Klinta 1 and Bjärsjölagård 2) previously described by Mehlqvist et al. (2012, 2014). Scylaspora klintaensis has its FAD in the Klinta 1 drillcore at $112 \mathrm{~m}$, where the succession is dated as Ludfordian (Mehlqvist et al. 2012). In the Klinta section, the same species occur at $14.08 \mathrm{~m}$ (Fig. 4). This correlation also agrees well with chemostratigraphic data (Wigforss-Lange 1999, 2007; Jeppsson et al. 2012). 


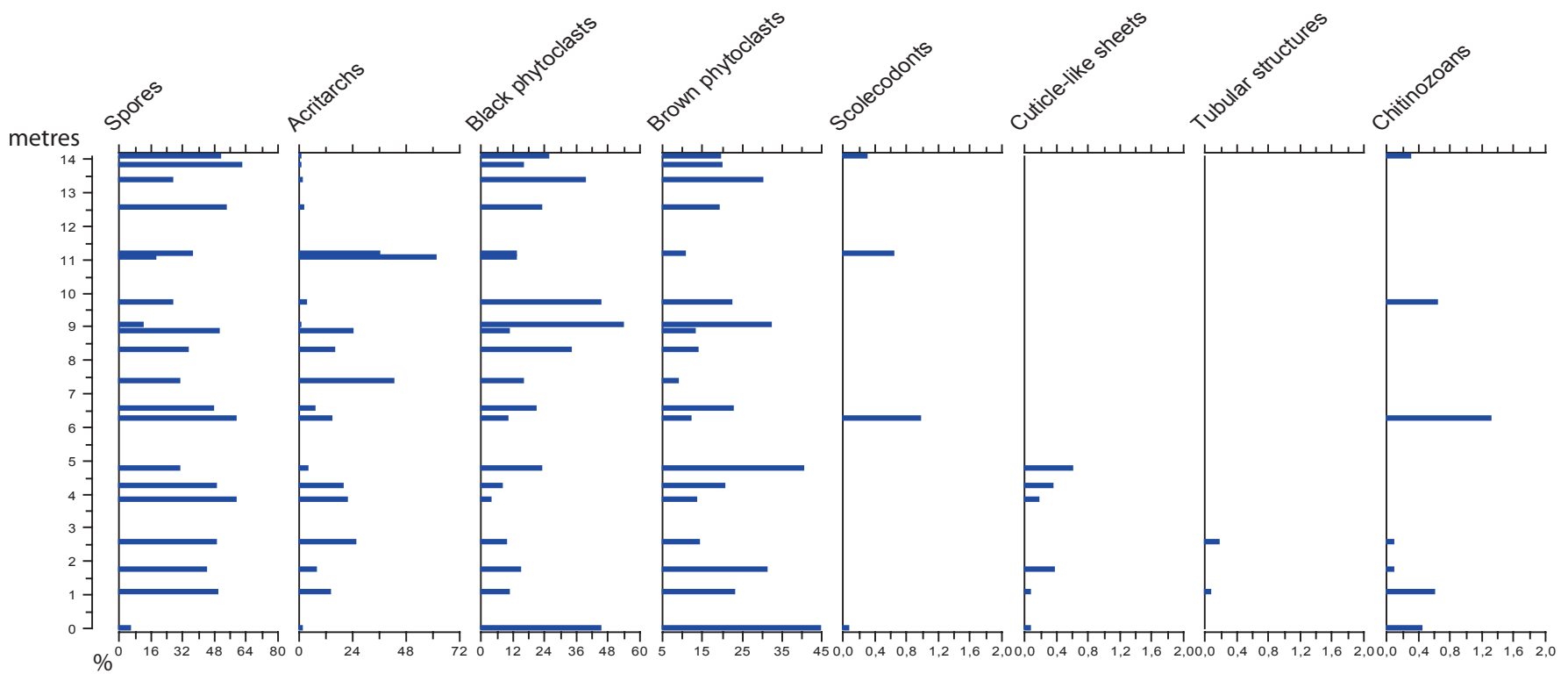

Figure 5 Palynofacies results, showing the relative abundance of the different components of organic matter in the residues from the studied samples. Note that x-axes for marine microfossils only represent $2 \%$.

Based on the palynofacies analysis, with an extremely high relative abundance of terrestrially-derived organic matter (spores and phytoclasts), a paralic environment is proposed for the basal and the topmost part of the succession. The close proximity to land is inferred by the high proportions of spores, which reflect a restricted catchment area, and the assemblage most probably represents the local flora growing on delta plains and with spores transported into the marine setting.

Relatively high abundances of acritarchs occur at $7 \mathrm{~m}$ and $11 \mathrm{~m}$ above the base of the section (Figs 5, 6). Considering the characteristics of the depositional environment, these deviations represent episodes of higher flood surges. In the shallow tide-dominated environment, even minor oscillations in water energy and/or water level will undoubtedly affect the sedimentation. The oxygen isotope composition also shows a minor depletion of ${ }^{18} \mathrm{O}$ at the upper level of acritarchs abundance (at $11 \mathrm{~m}$; Fig. 6). This may reflect climate changes signalling higher temperatures (melting ice sheets); but it may also reflect diagenesis, as the oxygen isotope is extremely sensitive to diagenetic alteration under the influence of meteoric waters. The carbon isotope composition shows no corresponding excursion (Fig. 6).

The extreme conditions in the marine environment characterised by an increase of cyanobacteria, cerebroid ooids and evaporite tracers, combined with extinctions of conodont faunas and fish (Jeppsson \& Aldridge 2000; Eriksson et al. 2009), are not reflected in the terrestrial vegetation. The terrestrial palynological signal reflects, instead, a robust, well-established and stable early flora throughout the studied succession, which contradicts results proposed by Stricanne et al. (2006) suggesting that both marine and terrestrial realms were synchronously affected during the Lau Event. We argue that the extinction during the Lau event is partly due to regression affecting local marine faunas, which seemingly didn't affect the terrestrial environments.

\section{Comparison with other assemblages}

Here, we compare the Klinta assemblage with coeval palynomorph suites from Baltica, Avalonia and that part of Laurentia presently represented in Scotland. The relevant intervals for comparison were selected from those publications that provide data sets spanning larger intervals than the Ludlow. Numerous publications have dealt with late Silurian miospore assemblages from areas further afield, but those studies are beyond the scope for detailed comparisons in this paper and will be addressed in a future study comparing larger Swedish datasets. Examples of assemblages and miospore zonations for further comparisons from other palaeocontients include those from Pennsylvania (Laurentia: Beck \& Strother 2008) and the Cantabrian Mountains (northern Spain: Richardson et al. 2001).

Gondwanan assemblages have been documented in many publications; e.g., Rubinstein \& Steemans (2002) comprehensively dealt with miospore assemblages spanning the SilurianDevonian boundary from the Ghadamis Basin in Libya, and Spina \& Vecoli (2009) described a coeval spore assemblage from the Tunisian part of the same basin. Other studies of somewhat younger (Devonian) spore assemblages from Tunisia were presented by, e.g., Loboziak et al. (1992). Additionally, there is a range of publications on miospore assemblages from the Precordillera Basin, Argentina; one of the latest examples being that of Garcia Muro et al. (2014), who described upper Silurian miospore suites.

Late Silurian spore assemblages from China were described by Wang \& Li (2000) from northern Jiangsu, and Wang et al. (2005) documented a spore assemblage from Guamgyuan, Sichuan.

\subsection{Baltica}

Hagström (1997) describes miospore assemblage from Gotland, from material comprising middle Llandovery to upper Ludlow strata representing a shallowing-up sequence. Marine deposits prevail in the lowermost part of the drillcores and more nearshore, possibly deltaic, deposits in the uppermost part of the succession represented by the Burgsvik Beds of Ludfordian age. The Burgsvik beds are coeval to the Klinta succession and is the interval hosting the most abundant spore assemblages from Gotland (Gray et al. 1974; Hagström 1997). Fourteen species, notably the tetrad Pachytetras rugosa and the trilete spores Apiculiretusispora ? burgsvikensis, Artemopyra brevicosta, Cymbohilates sp., Hispanaediscus verrucatus and Synorisporites cf. libycus, are shared between the present study and the coeval assemblages from Gotland. Species that occur 


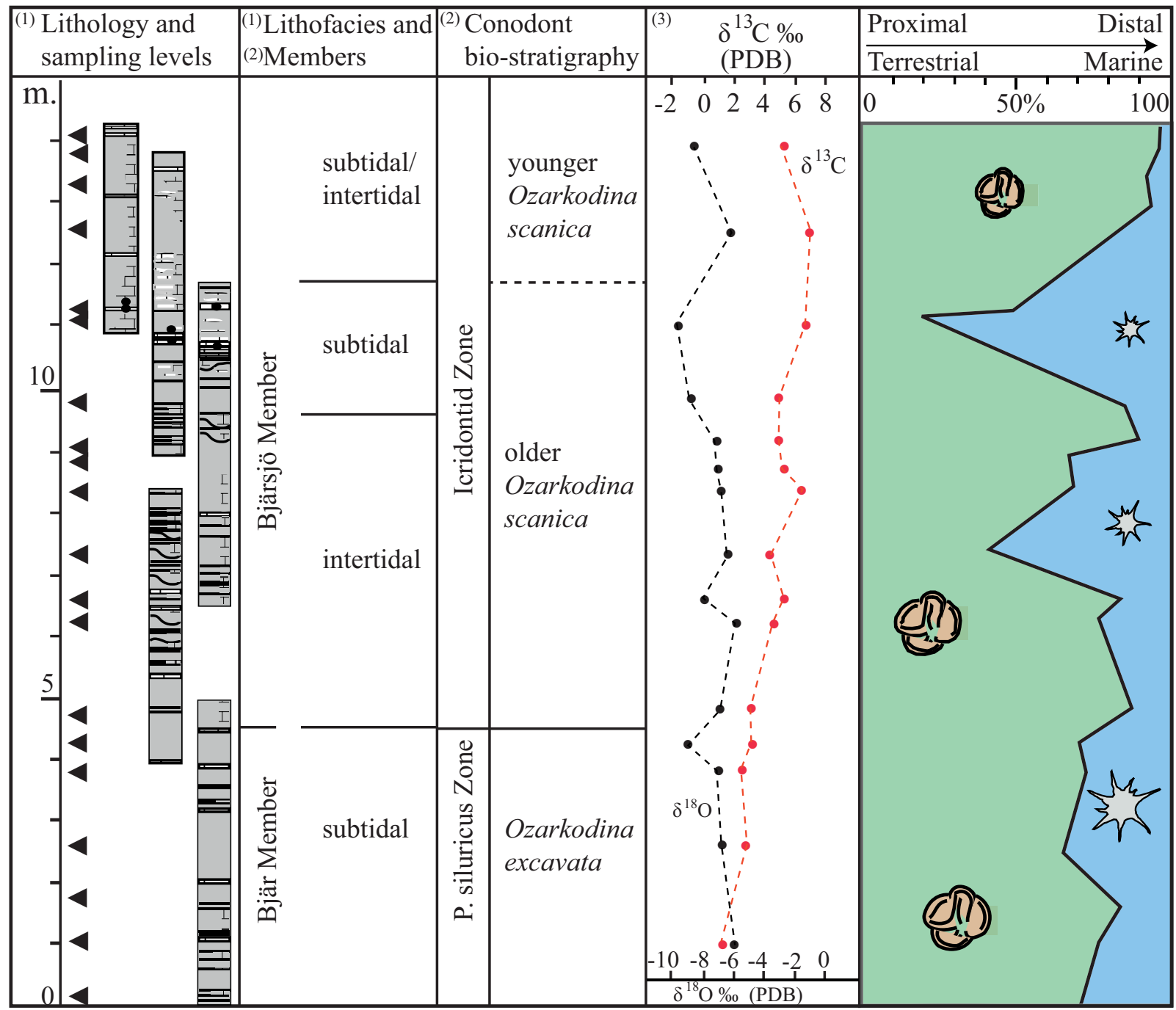

Figure 6 A compilation of data from this study and previously published results from the studied interval. The chart records the proportion of terrestrial vs. marine palynomorphs in relation to lithofacies, conodont stratigraphy and carbon and oxygen isotope composition. The data have been obtained from the following publications: (1) Wigforss-Lange 2007; (2) Jeppsson 1975; Jeppsson \& Laufeld 1986; Jeppsson et al. 2012; (3) Wigforss-Lange 1999; Jeppsson et al. 2012).

in the Gotland assemblage, but are lacking from the current study, include Abditusdyadus chalazus, Cymbohilates microgranulatus and $C$. variabilis. The abundance data in Hagström (1997) is focused on the palynofacies and the relation between marine and terrestrial palynomorphs. The lack of percentage data for the spores hampers abundance comparison with the present study.

\subsection{Avalonia and present-day Scotland}

5.2.1. Avalonia. A late Wenlock to early Príidolí assemblage presented by Burgess \& Richardson (1995) from the Rumney Inlier (south Wales) and Towy Anticline (southwest Wales) has been compared to the Klinta assemblage. The Welsh successions comprise near-shore marine sediments and in the Ludfordian interval 16 spore taxa were identified (11 trilete spores and five cryptospore taxa), making the Klinta assemblage the more diverse. When comparing the relation between cryptospores and trilete spores, major differences exist between the two assemblages, as the Welsh Ludfordian assemblage is highly dominated by trilete spores (69\%). Some shared taxa, such as Laevolancis and Ambitisporites, are long-ranging, but shared stratigraphically important species include Artemopyra brevicosta, A. radiata, Hispanaediscus lamontii, H. major, H. verrucatus, Scylaspora scripta and Synorisporites cf. libycus. However, the presence of A. brevicosta, characteristic of slightly older assemblages in Avalonia, might signify that this taxon appears later in Baltica than in Avalonia and this agrees with previous observations (Wellman et al. 2013).

Beck \& Strother (2001) described a miospore assemblage from Nova Scotia (western Avalonia) from the Arisaig Group. The sediments comprise silisiclastic mudstone and siltstone deposits and represent an almost complete succession of Silurian strata. The assemblage from the Arisaig Group shows similarities to type sections in the Anglo-Welsh Basin (East Avalonia). In total, 36 different spore species were identified from the Arisaig Group, but the assemblage is less diverse than assemblages from the Anglo-Welsh Basin. We compare our Klinta assemblage with the interval represented by the McAdam Brook and Moydart formations of the Arisaig Group (dated to Ludlow and represented by the libycus-poecilomorphus Assemblage Zone). It should be noted that the Arisaig assemblage seems to have a larger catchment area with deposition more distal as compared to our study. The mentioned interval in the Arisaig Group contains 25 taxa, some of which are in open nomenclature, a diversity similar to the 26 taxa recorded from the Klinta assemblage. However, out of 13 spore genera 


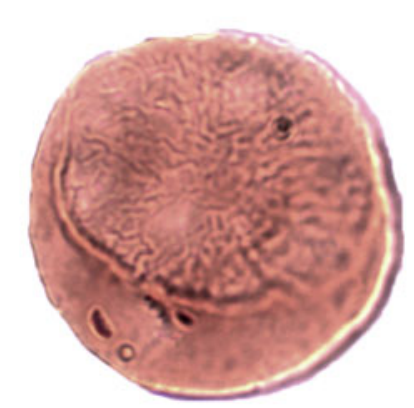

A

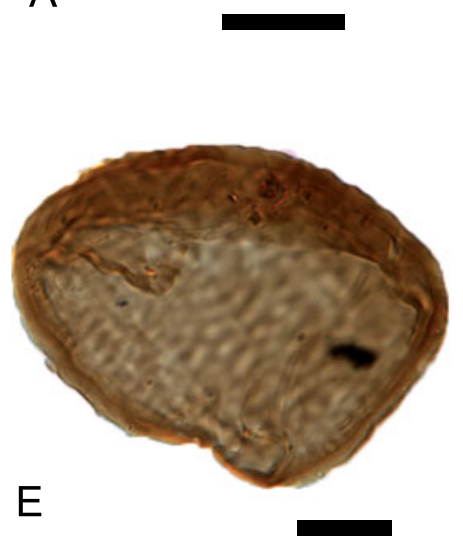

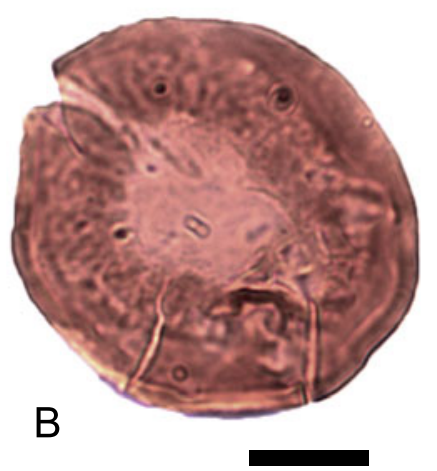
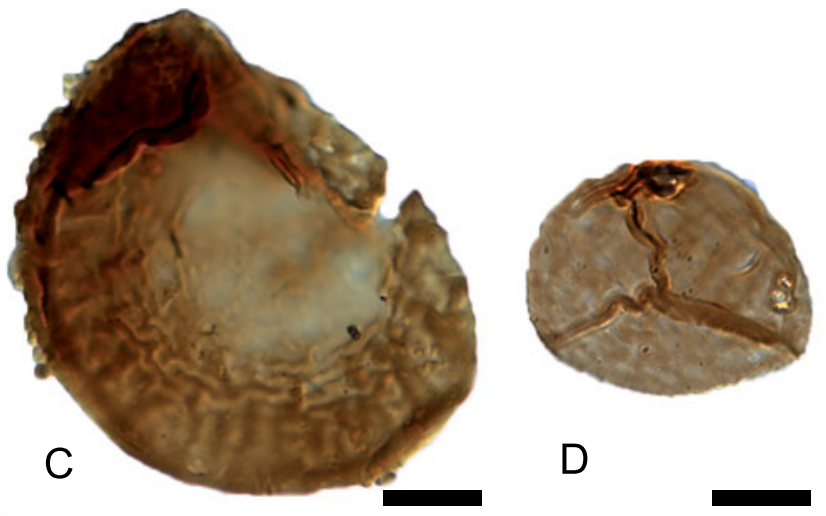

D
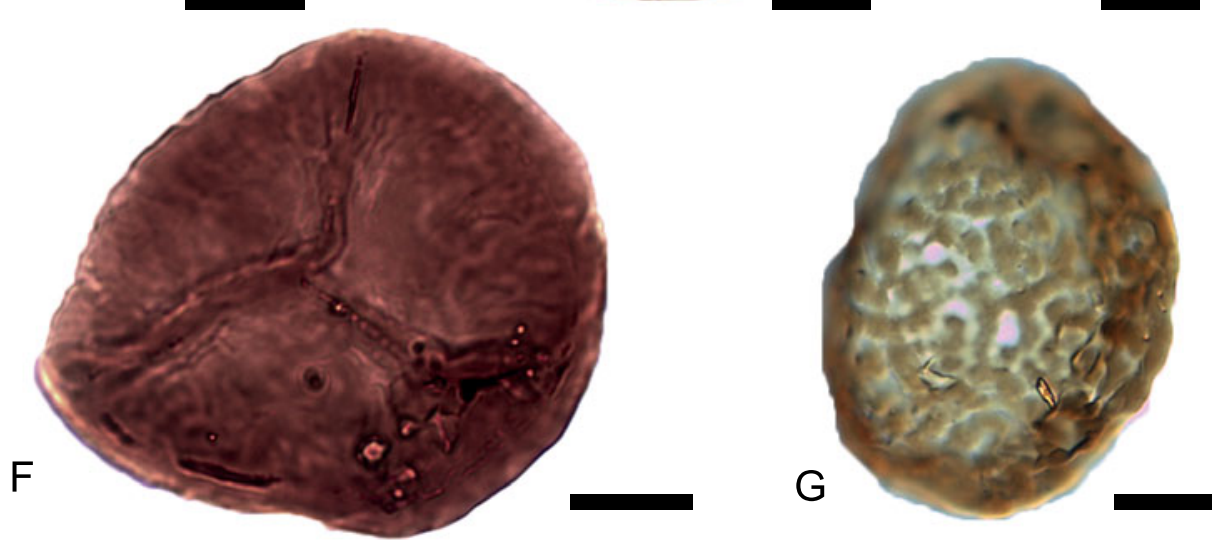

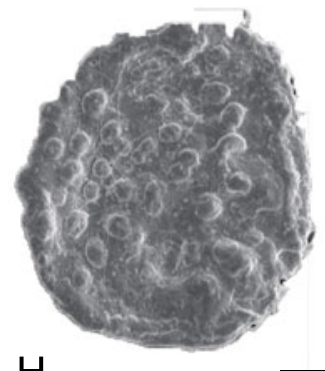

$\mathrm{H}$
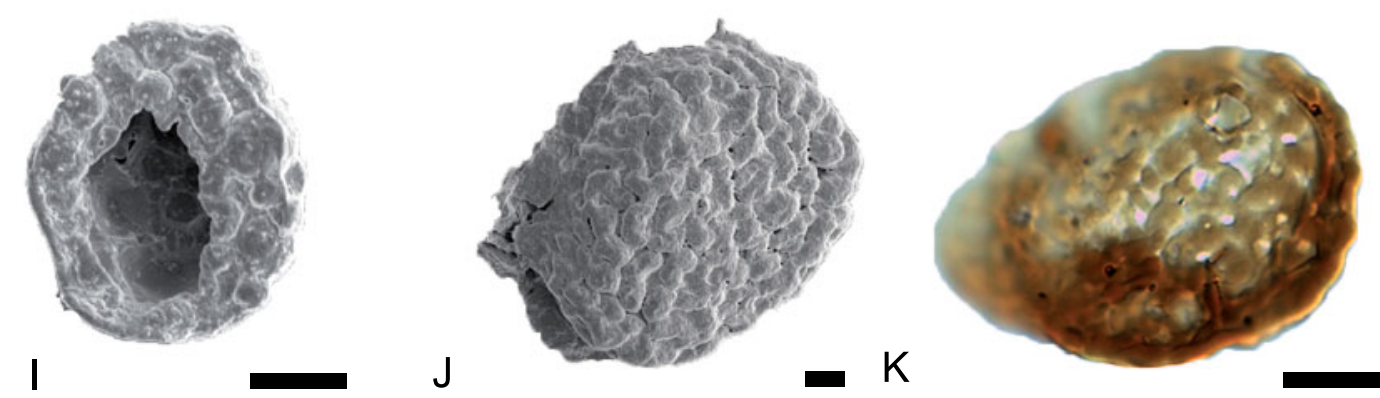

Figure 7 Light microscope images of dispersed spores from the Klinta outcrops, Skåne. Selected spore taxa: (A) Artemopyra brevicosta Burgess \& Richardson, 1991, LO11917t; (B-C) Artemopyra radiata Strother, 1991, LO11918t, LO11919t; (D) Synorisporties cf. libycus Richardson \& Ioannides, 1973, LO11920t; (E) Hispanaediscus major Burgess \& Richardson, 1995, LO11921t; (F) Scylaspora cf. vetusta (Rodriguez) Richardson et al., 2001, LO11922t; (G, J-K) Hispanaediscus lamontii Wellman, 1993, LO11923t, LO11924t, LO11925t; (H-I) Hispanaediscus verrucatus (Cramer) Burgess \& Richardson, 1991, LO11926t, LO11927t. Scale bars $=10 \mu \mathrm{m}$.

in the libycus-poecilomorphus Assemblage Zone of the Arisaig Group, only four are shared with those of this study. The following species are in common with the Klinta assemblage: T. medinensis, A. avitus, A, dilutus, L. divellomedia, L. plicata, $H$. verrucatus, H. major, A. parvus, D. murusattenuata and $D$. murusdensa.

5.2.2. Scotland. Wellman (1993) described a late Wenlock or early Ludlow spore assemblage from the Stonehaven Group in Scotland. The Stonehaven Group, exposed in the Midland Valley of Scotland, comprises continental sediments overlying Cambro-Ordovician deposits and is followed by a sequence of Lower Old Red Sandstone deposits (Wellman 1993). The spore assemblages are highly dominated by cryptospores (c. $88 \%$ ), and trilete spores only make up $8 \%$ of the assemblage, very similar to the numbers observed from Klinta. The trilete spores in the Scottish assemblage are dominated by $A$. avitus and $A$. dilutus (just as in Klinta), whilst ornamented trilete spores are rare. Cryptospores are dominated by the genera Laevolancis, Tetrahedraletes and Dyadospora; this is also consistent with the Klinta assemblage.
At species level, ten species are shared with the present study (Artemopyra brevicosta and Hispanaediscus lamontii and representatives of the genera Ambitisporites, Archaeozonotriletes, Dyadospora, Laevolancis and Tetrahedraletes). Species occurring in the Scottish assemblage, but lacking in this study, include Cheilotetras caledonica, Hispanaediscus wenlockensis and Psedodyadospora petasus. In conclusion, the Stonehaven assemblage shows great similarities to the Klinta assemblage.

5.2.3. Summary. In summary, our comparison of the Klinta assemblage not surprisingly reveals the closest similarities with the Gotland flora with respect to the representation of taxa. Regarding the Avalonian assemblages outlined above, significant similarities occur at generic level, whilst the abundance data show major discrepancies in that most coeval assemblages are strongly dominated by trilete spores. A very close match is evident with the slightly older assemblage (described as Wenlock or early Ludlow) from the Stonehaven Group in Scotland. 


\section{Conclusions}

- Samples from the upper Silurian Öved-Ramsåsa Group in Klinta, Sweden are dominated by the long-ranging cryptospores Laevolancis divellomedia-plicata and Dyadospora murusdensa-murusattenuata and the trilete spore Ambitisporites avitus-dilutus.

- Key taxa include Synorisporites cf. libycus, Hispanaediscus verrucatus and $H$. major, indicating a Ludlow age. This is consistent with marine biostratigraphic schemes.

- The palynofacies results imply a tidally influenced environment, strongly supporting previous interpretations based on sedimentological observations. The high proportions of spores infer a close proximity to land and the spores reflect the local flora inhabiting delta plains or the hinterland.

- The dominance of generally the same taxa throughout the studied interval indicates a steady flora on land, despite significant environmental changes in the marine environment.

- Comparisons with coeval assemblages elsewhere show a relatively high portion of shared taxa with Gotland and slightly older Welsh assemblages.

\section{Acknowledgments}

This research was supported by the Swedish Research Council under grant LUCCI (Lund University Carbon Cycle Centre) and by the Royal Swedish Academy of Sciences Research Fellow funded through the Knut and Alice Wallenberg Foundation. Russ Harms, GeoLab Ltd., is thanked for palynological processing. Mike Pole is thanked for language review. Charles Wellman and Philippe Steemans are thanked for constructive criticism and suggestions for improving this paper.

\section{References}

Badawy, A. S., Mehlqvist, K., Vajda, V., Ahlberg, P. \& Calner, M 2014. Late Ordovician (Katian) spores in Sweden - oldest land plant remains from Baltica. GFF 136(1), 16-21.

Bassett, M. G. 1985. Silurian stratigraphy and facies development in Scandinavia. In Gee, D. G. \& Stuart, B. A. (eds) The Caledonid Orogen-Scandinavia and Related Areas, 283-92. John Wiley \& Sons.

Batten, D. J. 1996. Palynofacies and palaeoenvironmental interpretation. Chapter 26A. In Jansonius, J. \& McGregor, D. C. (eds) Palynology: Principles and Applications 3, 1011-64. Dallas, Texas: American Association of Stratigraphic Palynologists Foundation.

Beck, J. H. \& Strother, P. K. 2001. Silurian spores and cryptospores from the Arisaig group, Nova Scotia, Canada. Palynology 25 , $127-77$

Beck, J. H. \& Strother, P. K. 2008. Miospores and Cryptospores from the Silurian Section at Allenport, Pennsylvania, USA. Journal of Paleontology 82, 857-83.

Bromell, M. von. 1725-1729. Lithographica Svecana specimen secundum. Acta Literaria et scientiarum Sveciae Upsaliae publicata 2 , continuens annos 1725-1729. Upsaliae \& Stockholmiae.

Burgess, N. D. \& Richardson, J. B. 1991. Silurian cryptospores and miospores from the type Wenlock area, Shropshire, England. Palaeontology 34, 601-28.

Burgess, N. D. \& Richardson, J. B. 1995. Late Wenlock to Early Prídolí cryptospores and miospores from south and southwest Wales, Great Britain. Palaeontographica 236, 1-44.

Eichstädt, F. 1888. Anteckningar om de yngsta öfversiluriska aflagringarna i Skåne. Geologiska Föreningens i Stockholm Förhandlingar 10, $132-56$

Eriksson, M. E., Nilsson, E. K. \& Jeppsson, L. 2009. Vertebrate extinctions and reorganizations during the Late Silurian Lau Event. Geology 37, 739-42.

Frost, R. T. C., Fitch, F. J. \& Miller, J. A. 1981. The age and nature of the crystalline basement of the North Sea Basin. In Illing, L. V. \& Hobson, G. D. (eds) Petroleum Geology of the Continental Shelf of North-West Europe, 43-57. London: Institute of Petroleum.
García Muro, V. J., Rubinstein, C. V. \& Steemans, P. 2014. Upper Silurian miospores from the Precordillera Basin, Argentina: biostratigraphic, palaeonvironmental and palaeogeographic implications. Geological Magazine 151, 472-90.

Grahn, Y. 1996. Upper Silurian (upper Wenlock-lower Přídolí) Chitinozoa and Biostratigraphy of Skåne, Southern Sweden. GFF 118, 237-50.

Gray, J., Laufeld, S. \& Boucot, A. J. 1974. Silurian trilete spores and spore tetrads from Gotland: Their implications for land plant evolution. Science 185, 260-63.

Grönwall, K. A. 1897. Öfversikt af Skånes yngre öfversiluriska bildningar. Geologiska Föreningens i Stockholm Förhandlingar 19 , $188-244$.

Hadding, A. 1927. The pre-Quaternary sedimentary rocks of Sweden. 1. A survey of the pre-Quaternary sedimentary rocks of Sweden. Lunds Universitets Arsskrift, N.F. Avd. 2 23(5), 11-39.

Hadding, A. 1933. The pre-Quaternary sedimentary rocks of Sweden. 5. On the organic remains of the limestones. Lunds Universitets Arsskrift, N.F. Avd. 2 29(4), 1-262.

Hagström, J. 1997. Land-derived palynomorphs from the Silurian of Gotland, Sweden. GFF 119, 301-16.

Hagström, J. \& Mehlqvist, K. 2012. The dawn of terrestrial ecosystems on Baltica: First report on land plant remains and arthropod coprolites from the Upper Silurian of Gotland, Sweden. Palaeogeography Palaeoclimatology and Palaeoecology 317-318C, 162 70 .

Jeppsson, L. 1975. Aspects of Late Silurian conodonts. Fossils and Strata 6, 1-79.

Jeppsson, L., Talent, J. A., Mawson, R., Andrew, A., Corrandini, C., Simpson, J., Wigforss-Lange, J. \& Schönlaub, H. P. 2012. Late Ludfordian correlations and the Lau Event. In Talent, J. A. (ed.) Earth and Life, International Year of Planet Earth, 653-75. Dordrecht: Springer Verlag.

Jeppsson, L. \& Aldridge, R. J. 2000. Ludlow (Late Silurian) oceanic episodes and events. Journal of the Geological Society, London 157, 1137-48.

Jeppsson, L. \& Laufeld, S. 1986. The Late Silurian Öved-Ramsåsa Group in Skåne, southern Sweden. Sveriges Geologiska Undersökning, Ca 58, 1-45.

Larsson, K. 1979. Silurian tentaculitides from Gotland and Scania. Fossils and Strata 11, 1-180.

Loboziak, S., Steemans, P., Streel, M. \& Vachard, D. 1992. Biostratigraphie par miospores du Dévonien inférieur à supérieur du sondage MG-1 (Bassin d'Hammadah, Tunisie). Comparaison avec les données des faunes. Review of Palaeobotany and Palynology 74, 193-205.

Mehlqvist, K., Vajda, V. \& Steemans, P. 2012. Early land plant spore assemblages from the Late Silurian of Skåne, Sweden. GFF 134, 133-44.

Mehlqvist, K., Larsson, K. \& Vajda, V. 2014. Linking upper Silurian terrestrial and marine successions - palynological study from Skåne, Sweden. Review of Palaeobotany and Palynology 202, 114

Moore, G. T., Jacobson, S. R., Ross, C. A. \& Hayashida, D. N. 1994 A paleoclimate simulation of the Wenlockian (late early Silurian) world using a general circulation model with implications for early land plant paleoecology. Palaeogeography, Palaeoclimatology, Palaeoecology 110, 115-44.

Regnéll, G. 1960. The Silurian of Scania. - In Regnéll, G. \& Hede, J. E. (eds) The Lower Palaeozoic of Scania. The Silurian of Gotland. International Geological Congress, XXI Session, Norden 1960, Guidebook Sweden d, 3-43.

Richardson, J. B., Rodriguez, R. M. \& Sutherland, S. J. E. 2001. Palynological zonation of Mid Palaeozoic sequences from the Cantabrian Mountains, NW Spain: implications for inter-regional and interfacies correlation of the Ludford/Prídolí and Silurian/ Devonian boundaries, and plant dispersal patterns. Bulletin of the Natural History Museum, London (Geology) 57, 115-62.

Richardson, J. B. \& Ioannides, N. S. 1973. Silurian palynomorphs from the Tanezzuft and Acacus formations, Tripolitania, North Africa. Micropalaeontology 19, 257-307.

Richardson, J. B. \& McGregor, D. C. 1986. Silurian and Devonian spore zones of the Old Red Sandstone continent and adjacent regions. Geological Survey of Canada, Bulletin 364, 1-73.

Rubinstein, C. V. \& Steemans, P. 2002. Miospore assemblages from the Silurian-Devonian boundary, in borehole A1-61, Ghadamis Basin, Libya. In Steemans, P., Servais, T. \& Streel, M. (eds) Paleozoüc Palynology: a special issue in honour of Dr. Stanislas Loboziak. Review of Palaeobotany and Palynology 118(1-4), 397-421 
Scotese, C. R. van der Voo, R. \& Barett, S. F. 1985. Silurian and Devonian base maps. Philosophical Transactions of the Royal Society, London 309, 57-77.

Sherwood-Pike, M. A. \& Gray, J. 1985. Silurian fungal remains: probable records of the Class Ascomycetes. Lethaia 18, 1-20.

Spina, A. \& Vecoli, M. 2009. Palynostratigraphy and vegetational changes in the Siluro-Devonian of the Ghadamis Basin, North Africa. Palaeogeography, Palaeoclimatology, Palaeoecology 282, $1-18$.

Stricanne, L. Munnecke, A. \& Pross, J. 2006. Asessing mechanism of environmental change: Palynological signals across the Late Ludlow (Silurian) positive isotope excursion $\left(\delta^{13} \mathrm{C}, \delta^{18} \mathrm{O}\right)$ on Gotland, Sweden. Palaeogeography, Palaeoclimatology, Palaeoecology 230, 1-31.

Strother, P. K. 1991. A classification for the cryptospores. Palynology 15, 4-20.

Vecoli, M., Delabroye, A., Spina, A. \& Hints, O. 2011. Cryptospore assemblages from Upper Ordovician (Katian-Hirnantian) strata of Anticosti Island, Québec, Canada, and Estonia: palaeophytogeographic and palaeoclimatic implications. Review of Palaeobotany and Palynology 166, 76-93.

Wang, Y. \& Li, J. 2000. Late Silurian trilete spores from northern Jiangsu, China. Review of Palaeobotany and Palynology 111, $111-25$.
Wang, Y., Zhu, H. C. \& Li, J. 2005. Late Silurian plant microfossil assemblage from Guangyuan, Sichuan, China. Review of Palaeobotany and Palynology 133, 153-68.

Wellman, C. H. 1993. A land plant microfossil assemblage of Mid Silurian age from the Stonehaven Group, Scotland. Journal of Micropalaeontology 12, 47-66.

Wellman, C. H., Steemans, P. \& Vecoli, M. 2013. Palaeophytogeography of Ordovician-Silurian land plants. In Harper, D. A. T. \& Servais, T. (eds) Early Palaeozoic Biogeography and Palaeogeography. Memoirs of the Geological Society, London 38, 461-76.

Wigforss-Lange, J. 1999. Carbon isotope $\delta^{13} \mathrm{C}$ enrichment in Upper Silurian (Whitcliffian) marine calcareous rocks in Scania, Sweden. GFF 121, 273-79.

Wigforss-Lange, J. 2007. Tidal facies in the Upper Silurian ÖvedRamsåsa Group of Scania, Sweden: linkages of radial and cerebroid ooids and evaporite tracers to subtidal, lagoonal environment. GFF 129, 7-16.

Wikman, H. \& Bergström, I. 1987. Provisoriska översiktliga bergrundskartan Malmö. Sveriges Geologiska Undersökning Ba 40. (Map)

Zeh, A. \& Gerdes, A. 2010. Baltica- and Gondwana-derived sediments in the Mid-German crystalline rise (Central Europe): Implications for the closure of the Rheic Ocean. Gondwana Research 17, 25463.

Ziegler, P. A. 1984. Caledonian and Hercynian crustal consolidation of Western and Central Europe - a working hypothesis. Geologie en Mijnbouw 63, 93-108.

MS received 20 February 2014. Accepted for publication 12 June 2014. 